\title{
ANCIENT AND MODERN IMPERIALISM ${ }^{\star}$
}

\author{
By THOMAS HARRISON
}

'For him the streets of the great city of learning which we wished to build lay all clearly laid out before his mind'. ${ }^{1}$ These words describe the first Rathbone Professor, the imposing John Macdonald Mackay who arrived in Liverpool, after a spell in St Andrews, at the precocious age of twenty-eight. Mackay was always portrayed in the image of the modern-day prophet. This was not only a matter of his posture, seen in a famous Liverpool picture in which he is represented pointing the so-called New Testament group of his fellow university progressives to the Promised Land (Figure 1), but also of his rambling style of speech (his lectures lasted nearly two hours) and in the characteristic pause, as the archaeologist John Garstang observed, after you addressed a question to him: 'an interval during which his eyes roamed among things unseen'. ${ }^{2}$ Lytton Strachey, briefly a pupil, put it more brutally: 'Professor Mackay is very weird and somewhat casual' ${ }^{3}$ But with all this, as my opening quotation suggests, Mackay was one of the chief architects of the faculty and university; discoursing passionately, for example, on the need for Liverpool to maintain its distance from the 'repellent American type' (of which he evidently knew very little). ${ }^{4}$ By comparison with the great Mackay, and still more with my immediate predecessors, I feel I must begin by lowering expectations. You may get rambling, but it won't I hope be mystical and it will not last for two hours. The topic might just have appealed to the great Mackay, however, not only because it takes us

* This paper was given as an inaugural lecture (as Rathbone Professor of Ancient History and Classical Archaeology) at the University of Liverpool on 26 March 2007. I am grateful to the editors for their refinements - and for allowing me to reproduce it here in a form close to the original text.

1 B. Pares, cited in P. E. H. Hair, 'The Real Mackay', in P. E. H. Hair (ed.) Arts, Letters, Society. A Miscellany Commemorating the Centenary of the Faculty of Arts at the University of Liverpool, Liverpool Historical Studies no. 15 (Liverpool, 1996), 192.

2 Cited by Hair (n. 1), 187. For the length of Mackay's lectures see F. W. Walbank, Arts at Liverpool. The First Hundred Years (Liverpool, 1998), 6.

3 Hair (n. 1), 205 n. 21, continuing: 'The first difficulty is to hear what he is saying as he speaks in a most extraordinary sing-song. When that has been mastered, the connexion between the lecture and Roman history. Lastly, but most important, to prevent and curb shrieks of laughter.'

4 Ibid., 195. 


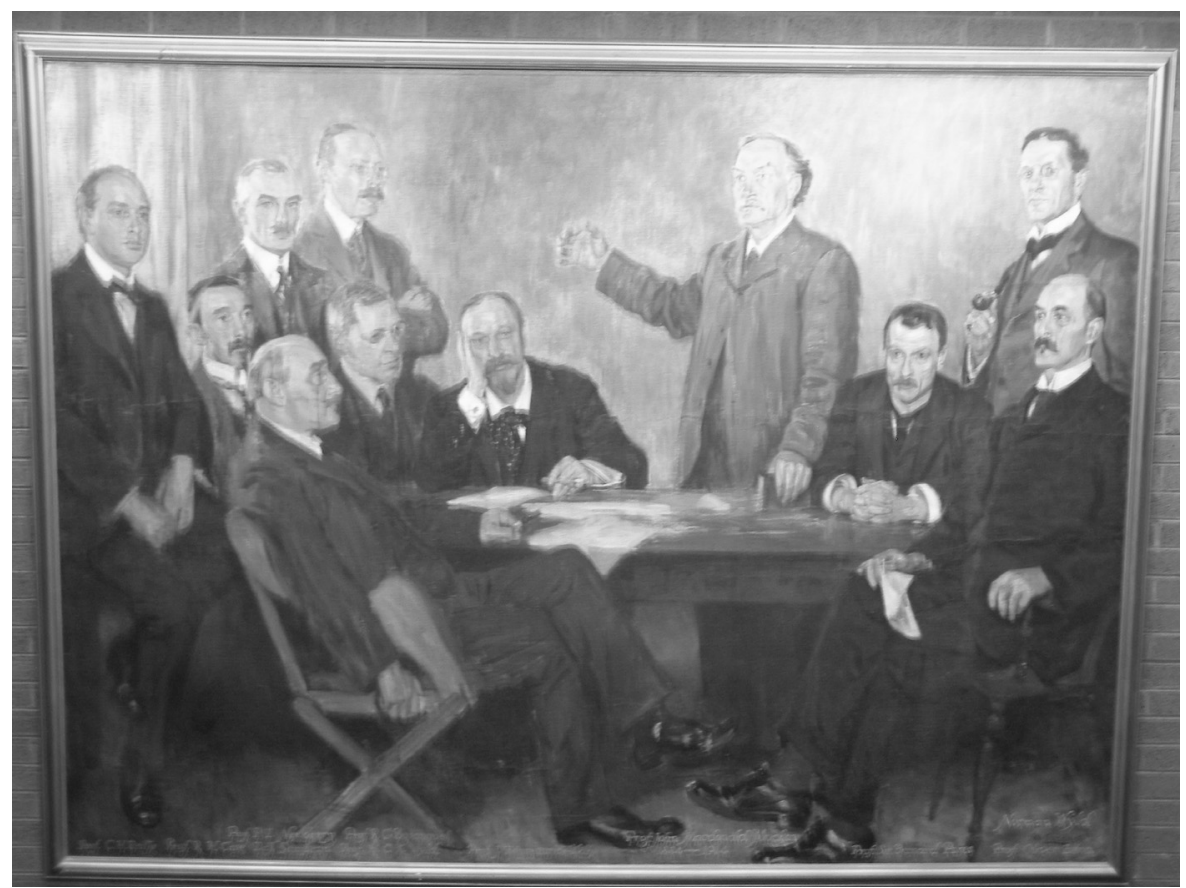

Figure 1. 'The New Testament Group', Albrecht Lipczinski, 1913-15. Reproduced by permission of the University of Liverpool Art Collections.

back to his own time as much as to antiquity, but also because of his evident commitment to the practical applicability of his subject. ${ }^{5}$

'In the eternal translatio imperii of history, the transfer or succession of empires, America is the new heir of Rome, and it is a cliché of political analysis that America is now as globally dominant as the Roman empire.' Comparisons of contemporary America with Rome have been everywhere recently. Respectable journalists, neocon hawks, bloggers, cartoonists have all exploited the comparison. My quotation just now came from someone with a unique relationship with the city of Liverpool, none other than Boris Johnson MP (Figure 2). ${ }^{6}$ The comparison can, of course, be developed in a number of different ways. In the early years of the so-called 'Bush doctrine' in foreign

5 Ibid., 204 n. 17.

6 B. Johnson, The Dream of Rome (London, 2006) 43. Johnson was compelled by the then Conservative leader Michael Howard to visit Liverpool to apologize for a leading article in the Spectator (16 October 2004) asserting Liverpudlians' 'mawkish sentimentality' and 'vicarious victimhood'. For his written apology, see <http:/www.boris-johnson.com/archives/2004/10/ apologetic_in_liverpool_1.php>, accessed 14 November 2007. 


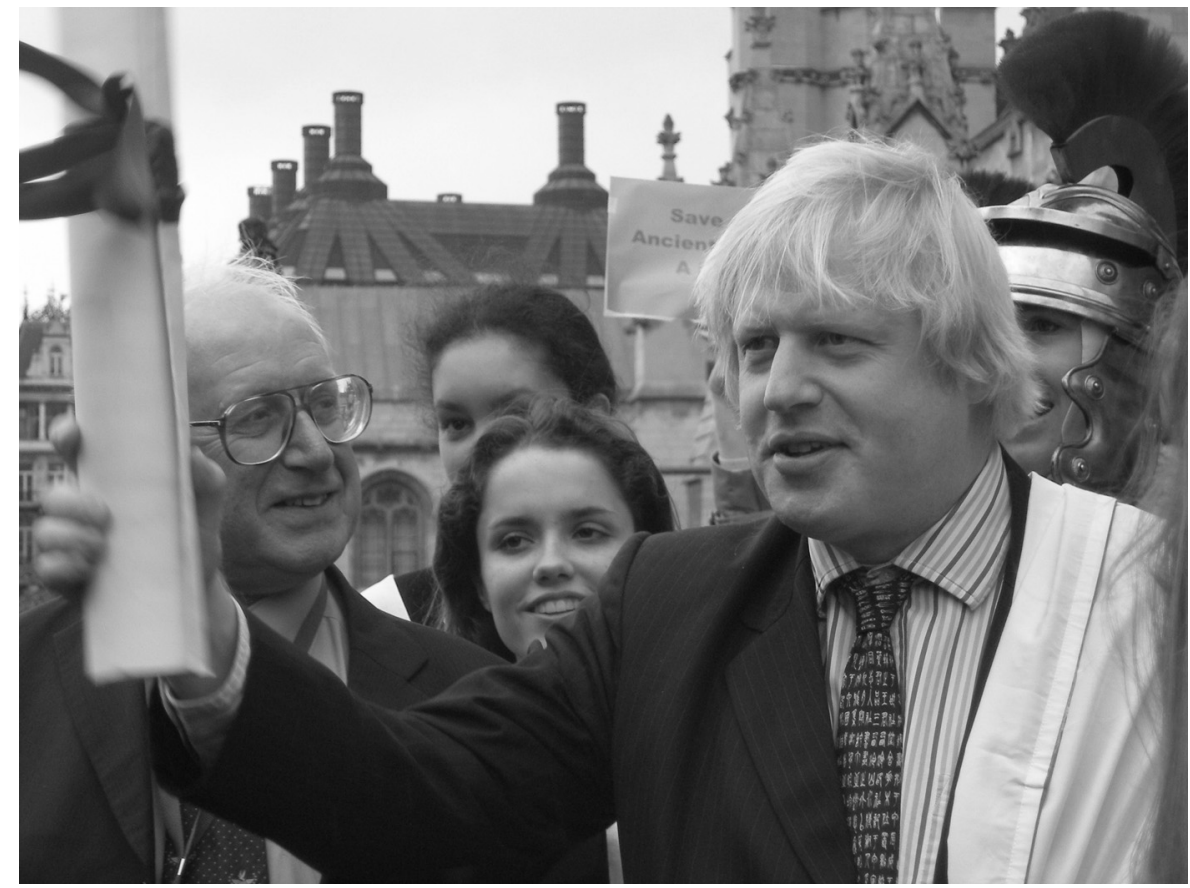

Figure 2. Boris Johnson MP togate, Houses of Parliament, 14 May 2007. Photo by Patricia Stoughton.

affairs, when the word 'empire' first came out of the closet in the American context, or even earlier with the first realization of a 'unipolar' world order in the light of the first Gulf War, the comparison was pretty consistently positive. Two of the key figures of neo-conservative thought, William Kristol and Robert Kagan summarized the position of the US after Desert Storm, in a famous manifesto, as '[holding] a position unmatched since Rome dominated the Mediterranean world'. ${ }^{7}$ Similarly, Samuel Huntington, author of the notorious pamphlet on the 'clash of civilisations', looked back (nostalgically?) to the 'near-universal civilization' of the Roman empire, something which 'can only be the product of universal power'. 8

Increasingly, the comparison has become pessimistic. From a relatively liberal perspective, Bush has been compared with (amongst others) Commodus, Caligula, and Nero ('Nero...fiddled while Rome

7 W. Kristol and R. Kagan, 'National Interest and Global Responsibility', in I. Stelzer (ed.) The Neocon Reader (New York, NY, 2004), 57.

8 S. Huntington, 'If Not Civilizations, What? Paradigms of the Post-Cold War World', in idem (ed.), The Clash of Civilizations. The Debate (New York, NY, 1996), 64. 
burned. George Bush takes yet another vacation', in the words of one web respondent ${ }^{9}$ ). Commentators have focussed on the transition from Roman republic to empire, and suggested that the invocation of freedom is no more than a power grab. At the same time, from a more conservative perspective, for his legalization of the status of illegal immigrants Bush has been compared with Theodosius, the emperor who allowed the Visigoths into the Roman empire. ${ }^{10}$ In tentatively post-imperial Britain, the focus has been less on power, more on mod cons. The Oxford historian Bryan Ward Perkins, in his The Fall of Rome and the End of Civilisation (a title, he insists, chosen by his publisher), highlighted the huge drop in standard of living that came with the decline of Rome and warned his readership against showing the same complacency. ${ }^{11}$ Boris Johnson was concerned to contrast the Roman Empire's ability to overcome the forces of what he termed 'Romanoscepticism' with the failures of the European Union to engage our hearts and minds. ${ }^{12}$

What I would like to do here is to show how such analogies between ancient and modern empires have informed, and how they continue to inform, our understanding, both of ancient history and of our own contemporary experience. Such analogies have a long history. The focus on America as the new Rome is reminiscent, for example, of the words of one of the most famous classicists of the twentieth century (as well as a champion of the League of Nations), Gilbert Murray, who envisaged the mantle of supremacy amongst 'organised nations' passing to America: 'waiting across the Atlantic a greater Rome which may at the best establish a true world Peace, and will at the worst maintain in an ocean of barbarism a large and enduring island of true Hellenic life'. ${ }^{13}$ The history is a much broader and deeper one, however. The analogy of ancient and modern empires has been expressed through any number of means: through classical architecture, through exam papers asking candidates to compare Rome's

9 TexasDemO, responding to a blog by Gary Hart, 24 August 2006: <http://www. huffingtonpost.com/gary-hart/twentyfirst-century-rome_b_27944.html>, accessed 14 November 2007. A number of illustrations and cartoons Romanize Bush: see e.g. Jim Wallis, 'Dangerous Religion. George W. Bush's theology of empire', Sojourners Magazine Sept-Oct 2003.

${ }_{10} \mathrm{~S}$. LaTulippe, 'George W. Bush, an American Theodosius', <http://www.lewrockwell. com/orig4/latulippe4.html>, accessed 14 November 2007, concluding: 'For Rome, they [arguments for legalization] all proved wrong. Theodosius' policy set in motion a chain of events that led to the ultimate demise of the Western Roman Empire.'

11 B. Ward Perkins, The Fall of Rome and the End of Civilization (Oxford, 2005), 183.

12 Johnson (n. 6), 22-7.

13 G. Murray, Hellenism and the Modern World (London, 1953) 53, 58. For Murray, see now Christopher Stray's superb collection, Gilbert Murray Reassessed. Hellenism, Theatre and International Politics (Oxford, 2007). 
expansion with that of other 'great conquering states' (that is, a Manchester exam paper of the early $1890 \mathrm{~s}^{14}$ ), or through the heroizing representation of imperial heroes. To cite Boris Johnson again, 'throughout history, people have tried on bits of roman apparel to see how it fits; and sometimes it looks quite good'. ${ }^{15}$

One particularly rich context for the history of the analogy of ancient and modern imperialism is the late nineteenth and early twentieth centuries. With the rise of the anti-imperialist movement, this was a period we might fairly see - I will be focussing particularly on Britain, but the same would be true in other contexts, for example the United States - as one of particularly self-conscious reflection on the morality and viability of empire. It is a period also that gave rise to a number of peculiarly revealing books, articles, and pamphlets seeking to compare ancient and modern experiences of imperialism. Most famous of these, perhaps, are the liberal politician James Bryce's pamphlet comparing the Roman empire with British India, and the former consul general of Egypt, Evelyn Baring, the Earl of Cromer's 1910 presidential address to the Classical Association, Ancient and Modern Imperialism. ${ }^{16}$

What can we find in these works? They are interesting, first, in so far as they are revealing of the very different preoccupations of their own time. On a relatively frivolous note, for example, we can see distinctly British characteristics in the descriptions of Roman 'empire-builders'. So, in John Buchan's biography of Julius Caesar, Caesar has all the resolution, restraint, and athleticism of Buchan's novelistic heroes. He has the 'pioneer's passion', he admires and can get under the skin of Rome's subject peoples, and crucially he does not think too much: 'He had not stopped to think about an ultimate goal, believing, with Cromwell, that no man goes so far as he who does not know where he is going' ${ }^{17}$

A more serious contemporary concern is with the possibility of racial assimilation within empires. 'My main endeavour', Cromer wrote in a letter during his time in Egypt, 'ever since I have been here,

14 Owen's College Manchester, 1891-2 BA (Hons). I am grateful to Andrew Wilson for pointing this out to me.

15 Johnson (n. 6), 32. For a defence of the comparability of pre-modern and modern empires, see R. Jones and R. Phillips, 'Unsettling Geographical Horizons: Exploring Premodern and Non-European Imperialism', Annals of the Association of American Geographers 95.1 (2005) $141-61$.

16 J. Bryce, The Ancient Roman Empire and the British Empire in India (London, 1914); E. Baring, Earl of Cromer, Ancient and Modern Imperialism (London, 1910).

17 J. Buchan, Fulius Caesar (London, 2001; originally published London, 1932), 36; the same quotation from Cromwell is cited by Bryce (n. 16), 9. 
has been to fuse all these classes [Muslims, Copts, Syrians, Leventines, and Europeans, the 'civilising element' in his words] into one, and to drive...in the direction of making a nation of them' ${ }^{18}$ In his Ancient and Modern Imperialism, he worries away at the question of how and why the Romans apparently managed to assimilate their populations better than Britain, coming to the conclusion that the challenges they faced were not as steep (Rome had tribes to deal with, Britain nations). ${ }^{19}$ Issues of race and intermarriage loom more explicitly in Bryce's account, in which he somehow manages to present racial prejudice as a regrettable but - at least for the time being unavoidable impulse:

Now to the Teutonic peoples, and especially to the English and Anglo-Americans, the difference of colour means a great deal. It creates a feeling of separation, perhaps even of a slight repulsion. Such a feeling may be deemed unreasonable or unchristian, but it seems too deeply rooted to be effaceable in any time we can foresee. It is, to be sure, not nearly so strong towards members of the more civilised races of India, with their faces often full of an intelligence and refinement which witness to many generations of mental culture, as it is in North America towards the negroes of the Gulf Coast, or in South Africa towards the Kaffirs. Yet it is sufficient to be, as a rule, a bar to social intimacy, and a complete bar to intermarriage. ${ }^{20}$

Though Cromer fascinatingly accuses Rome of using a policy of divide and rule, the emphasis on the diversity of populations serves, for both him and Bryce, a very useful purpose: in justifying British tutelage. Bryce ends his work with a bloodcurdling scenario of what would happen if Britain were to withdraw from India, with one Indian people turning against another. For Cromer, 'to speak of self-government for India under conditions such as these is as if we were to advocate self-government for a united Europe'. ${ }^{21}$ (The Eurosceptic Boris Johnson controversially takes the violence of Indian partition partially to justify Cromer. ${ }^{22}$ )

These texts are not, however, for the ancient historian, mere curiosities, redolent only of the different circumstances of the authors' times. They can also reflect on our own understanding of ancient empires. As a discipline, ancient history is perhaps distinct in two ways: first, the limited primary evidence with which we can engage

18 Quoted by R. Owen, Lord Cromer. Victorian Imperialist, Edwardian Proconsul (Oxford, 2005), 331.

${ }^{19}$ Earl of Cromer (n. 16), 89-93.

20 Bryce (n. 16), 59-60.

21 Earl of Cromer (n. 16), 123.

22 Johnson (n. 6), 48. 
(although, of course, the body of these sources continues to be expanded); secondly, the extraordinary depth (and breadth) of the scholarly tradition within which we operate. The first characteristic forces us - or so we fondly imagine - to engage more ingeniously with our sources of evidence. In the often-quoted words of Iris Murdoch (of early Greek history), ancient history is 'a game with very few pieces where the skill of the player lies in complicating the rules. The isolated and uneloquent fact must be exhibited with a tissue of hypothesis subtle enough to make it speak. ${ }^{, 23}$ The increasing engagement with previous generations of scholarship is similarly enlightening. Looking at early twentieth-century works comparing ancient and modern empires allows one to explore how models derived from modern experience persist in contemporary scholarship, and to unsettle what may appear to be inevitable or natural features of our narratives.

One example of this is the idea of the 'balance sheet'. This was a term regularly used in discussions of the profitability of the British Empire for Britain, and which has been used since in discussions of the good or harm done by Britain and other European expansionist powers to their colonies. ${ }^{24}$ Good works and good intentions are seen here as a justification of empire, whilst at the same time acknowledging the downsides of empire: we tot up the pros and cons in two matching columns. So, for example, Cromer condemns what he sees as the early plundering of India's resources, but claims that, in the last fifty years, though mistakes may have been made, 'not a word of reproach can be breathed against the spirit which has animated their rule'. ${ }^{25}$ To illustrate his point, he tells a story, for example, of how a young Bengali protester against British rule, responded when asked what he would do if anarchy were to overcome India because of political unrest and his property were accidentally to be confiscated: " What should I do, sir?" was his reply; "I should apply to the High Court". British ideas of justice had so unconsciously penetrated into his mind that he could not conceive a [different] condition of affairs...'. In just the same way as Cromer, an earlier historian of Rome, Tenney Frank in his 1914 Roman Imperialism, admitted the 'ravages of civil war [in the late Republic], the irresponsible exactions of partisan leaders...the exactions of taxgatherers and of conniving

23 I. Murdoch, The Nice and the Good (London, 1968), 165.

${ }^{24}$ See, e.g., G. Clark, The Balance Sheets of Imperialism. Facts and Figures on Colonies (New York, NY, 1936).

${ }^{25}$ Earl of Cromer (n. 16), 70. 
governors' but judged that, with the introduction of the pax Romana by Augustus, all these were ended: 'Of far greater importance to the life of the empire than the occasional extensions of its limits was the orderly government now given it. ${ }^{26}$ Even the term 'balance sheet' made its way into the history of ancient empires, providing the title both for a chapter of Russell Meiggs' (still unsurpassed) book on the fifth-century BC naval 'empire' of the Athenians, and the subtitle of a famous essay by Moses Finley. ${ }^{27}$ In both of these cases, the focus is on the economic benefits and costs of empire, but it is also regularly applied to more intangible aspects of imperialism: the cultural benefits of being part of a larger community, for example; the sense of identity shared between imperialists and subjects; or the benign intentions of the imperialists. So, when the Athenian generals on the island of Samos in 439/8 BC swear according to the text of an inscription (Meiggs-Lewis, 56) to 'do and advise and say only what is good for the people of Samos...', my former teacher George Forrest asked: 'Did the men who swore that oath have their tongues in their cheeks, all of them? Or did one or two of them have a tear in their eye? ${ }^{28} \mathrm{He}$ describes - archly - the Athenians here as carrying a 'white man's burden'.

Now what is wrong with any of this? At one level, of course, we might consider it a perfectly legitimate task for the historian to stand back, and to weigh an empire on a set of moral scales that are unashamedly modern. Bridges and law courts and so on are all perfectly good things, and it is better, you might suppose, that empire is exercised in a benevolent fashion - no matter how paternalistically than self-servingly. Boris Johnson (with a distinctly Tory agenda, admittedly) has sought to do precisely this in assessing what we today would take and what we would leave from the Roman empire:

We would avoid the slavery and the mines and the pyschotic cult of the ego; the militarism and the cruelty. [Enough there, you might think, to put you off the whole package]. But we would want the religious tolerance, the racial tolerance, the intellectual tolerance and curiosity. We would surely want the laissez-faire government of the

26 T. Frank, Roman Imperialism (New York, NY, 1914), 353.

${ }_{27}$ M. I. Finley, 'The Athenian Empire: A Balance Sheet', in P. D. A. Garnsey and C. R. Whittaker (eds.), Imperialism in the Ancient World (Cambridge, 1978), 103-26, reprinted in M. I. Finley, Economy and Society in Ancient Greece, ed. B. D. Shaw and R. P. Saller (London, 1981), 41-61; R. Meiggs, The Athenian Empire (Oxford, 1972).

28 W. G. Forrest, 'Aristophanes and the Athenian Empire', in B. Levick (ed.), The Ancient Historian and his Materials. Essays in Honour of C. E. Stevens (Farnborough, 1975), 27. 
High Empire, in which the economy grew and people prospered with minimal bureaucracy and regulation. ${ }^{29}$

Romanization, the spread of baths and togas and Roman naming to the conquered peoples of the empire are for Johnson (as for Bryan Ward-Perkins and many others) a straightforwardly good thing. What the balance sheet fails to accommodate, however, in measuring the pros and cons of empire on a single sliding scale, is what is likely to have been the ambivalent attitude of those on the receiving end of imperial benefaction. This becomes pretty clear if you consider contemporary parallels, 'the strange mixture of attraction and repulsion that the West breeds' in the words of one contemporary writer. ${ }^{30}$ Reactions to the Iraq war are unsurprisingly extreme. (One Mr Fish cartoon, for example, has envisaged Bush as a Roman centurion, 'freeing' Jesus by nailing him to the cross.) $)^{31}$ The same questions can be asked, however, of more apparently positive, or neutral, results of 'soft' Western power. The Guardian journalist Jonathan Freedland has compared the attractions of togas and central heating with what the US offers the people of the world today: 'a similarly coherent cultural package, a cluster of goodies that remain reassuringly uniform wherever you are. It's not togas or gladiatorial games..., but Starbucks, Coca-Cola, McDonald's and Disney, all paid for in the contemporary equivalent of Roman coinage, the global hard currency of the $21 \mathrm{st}$ century: the dollar'. ${ }^{32}$ Leaving aside the superficiality or otherwise of these benefits, it is fairly obvious that ingesting Coca-Cola does not involve ingesting American cultural values, still less a commitment to US foreign policy goals. This is a point made, with reckless style, by Victor Davis Hanson:

These consumers of different races, religions, languages, and nations, who all wear Adidas, buy Microsoft computer programs, and drink Coke, are just as likely to kill each other as before - and still watch Gilligan's Island reruns on their international television screens afterward...there is little solace that some new global culture has ushered in a new period of perpetual peace. 33

${ }^{29}$ Johnson (n. 6), 198-9. No mention here of late Roman bureaucracy in administration, for which see, e.g., C. Kelly, Ruling the Later Roman Empire (Cambridge, MA, 2004).

${ }^{30}$ F. Ajami, 'The Summoning. "But They Said, We Will Not Hearken"', in Huntington (n. 8), 29: 'It is easy to understand Huntington's frustration with this kind of complexity, with the strange mixture of attraction and repulsion that the West breeds, and his need to simplify matters, to mark out the borders of civilization.'

31 Harper's Magazine, March 31 2006, reproduced at http://www.harpers.org/subjects/ MrFish/ArtistIllustratorOf/Cartoon.

32 The Guardian, 18 September 2002.

33 V. D. Hanson, Why the West was Won. Nine Landmark Battles in the Brutal History of Western Victory (London, 2001), 449. 
When the balance sheet extends beyond tangible benefits/drawbacks and begins to embrace the civilizing mission of the imperial power, another danger is introduced: that the historian ends up crediting as fact what are highly charged ideological claims. The quotation earlier from Tenney Frank, that the Roman empire of the Republican period was marked by the exactions of tax gatherers, is made in a more marked way by John Buchan in his life of Julius Caesar, but notably there he refers to it as a 'false imperialism', 'based on the interests of the capitalists, which regarded the provinces as mere milch-cows'. ${ }^{34}$ Benignly motivated imperialism, true imperialism, is implicitly acceptable. To return to the Athenian case, you can read in one important modern account of the Athenian empire that it was more or less a naval alliance, whose aims were to protect Greeks from Persians and to liberate Greeks under Persian domination'. ${ }^{35}$ Another recent account - recent in the terms of an ancient historian, at least introduces another problematic benefit into the balance sheet: the Athenians' supposed eradication of piracy from the Aegean. ${ }^{36}$ I say 'supposed' not because I doubt that they did something, but only because the attribution of piracy, like terrorism (or thuggee in the context of British India), can almost always be contested. ${ }^{37}$

The suggestion that the Athenians' empire grew innocently from a war of liberation against Persia leads me to another clear parallel between ancient and modern empires (though in this case the parallel can be said to be rooted more securely in ancient texts): that is, the idea of empire as acquired only accidentally or in self-defence.

Growing as trees grow, while others slept; fed by the faults of others as well as by the character of our fathers; reaching with the ripple of a resistless tide over tracts and islands and continents, until our little Britain woke up to find herself the foster mother of nations and the source of united empires? Do we not hail in this less the energy and fortune of a race than the supreme direction of the Almighty?

So Lord Rosebery's 1900 rectorial address at the University of Glasgow. ${ }^{38}$ More famously, it was remarked by J. R. Seeley (Professor of Latin at UCL before taking up the Chair of Modern History at

${ }^{34}$ Buchan (n. 17), 7.

35 S. Price and L. Nixon, 'The Size and Resources of Greek Cities', in O. Murray and S. Price (eds.), The Greek City from Homer to Alexander (Oxford, 1990), 138.

36 S. Hornblower, The Greek World 479-323 BC (London, 1983), 30-1; contrast Hornblower, A Commentary to Thucydides, vol. 1 (Oxford, 1991), 150.

37 Something appreciated by H. A. Ormerod in his Piracy in the Ancient World (Liverpool, 1924), 14.

${ }^{38}$ Quoted by T. Callander, The Athenian Empire and the British (London, 1961), 24. 
Cambridge), in his Expansion of England, that England had come to rule half the world 'in a fit of absence of mind'; ${ }^{39}$ the English needed to wake up and work to maintain the empire. (Buchan's Caesar similarly '[found] himself forced unwillingly to conquer the world' ${ }^{40}$ )

Similar patterns can be seen in the ancient accounts of Athenian and Roman expansion of, respectively, Thucydides and Polybius. (There is nothing accidental, by contrast, about the actions of the Persian empire-builder Cyrus.) Thucydides, for example, puts the following justification of empire into the Athenians' mouths (Thuc. 1.76.2):

We have done nothing extraordinary, nothing contrary to human practice, in accepting an empire when it was offered to us and then in refusing to give it up. Three very powerful motives prevent us from doing so - honour, fear and self-interest. And we were not the first to act in this way. It has always been a rule that the weak should be subject to the strong; besides we consider that we are worthy of our power.

\section{As Moses Finley commented:}

There is no programme of imperialism there, no theory, merely a reassertion of the universal ancient belief in the naturalness of domination.... Athenian imperialism employed all the forms of material exploitation that were available and possible in that society. ${ }^{41}$

We should have no truck with seeking motives, as they can essentially be read in.

Now (again) what is wrong with this? Protesting at her rival Monica Seles' habit of grunting as she hit a tennis ball, Martina Navratilova memorably remarked that she might not be doing it on purpose but that she could certainly stop it on purpose. The attribution of motives is more complex of course when you are dealing with a larger, more significant, historical pattern, but some of the lesson still holds. We are being offered a false choice: between, on the one hand, something unavoidable and, on the other, something cynically plotted by a whole people. Roman power, Polybius observes in fact, did not arise 'by chance or without the victors knowing what they were doing' (Polyb.

39 J. R. Seeley, The Expansion of England (London, 1883), 10. For Seeley, see P. Vasunia, 'Greater Rome and Greater Britain', in B. Goff (ed.), Classics and Colonialism (London, 2005), 38-64; for an account of how empire came to be so unconsciously accepted, see C. Hall and S. Rose, At Home with the Empire. Metropolitan Culture and the Imperial World (Cambridge, 2006).

40 Buchan (n. 17), 51, 68

41 Finley (n. 27), 125. 
1.63). Empires do not fall into laps, in Paul Veyne's phrase. ${ }^{42}$ (As Bryce quite fairly describes it, 'though they did not start out with the notion of conquering even Italy, [they] came to enjoy fighting for its own sake, and were content with slight pretexts for it. ${ }^{43}$ ) Though we may like to think of empires, at least at their apex, as stable entities (and it is certainly in that spirit that British writers looked back nostalgically to the Roman, and also to the Persian, empire ${ }^{44}$ ), in fact they are remade and re-imagined constantly by a whole range of individual and collective initiatives. In the famous dictum of Edward Said, moreover, empire depends upon the prior 'idea of empire'; it depends on a 'structure of attitude and reference' that frames the range of possibilities open to any individual. ${ }^{45}$ The idea of empire can be inculcated (and so found by historians) in all sorts of texts, institutions, and moments, domestic as well as high political. (As an illustration of this, figure 3 shows a montage from a Leeds school at the beginning

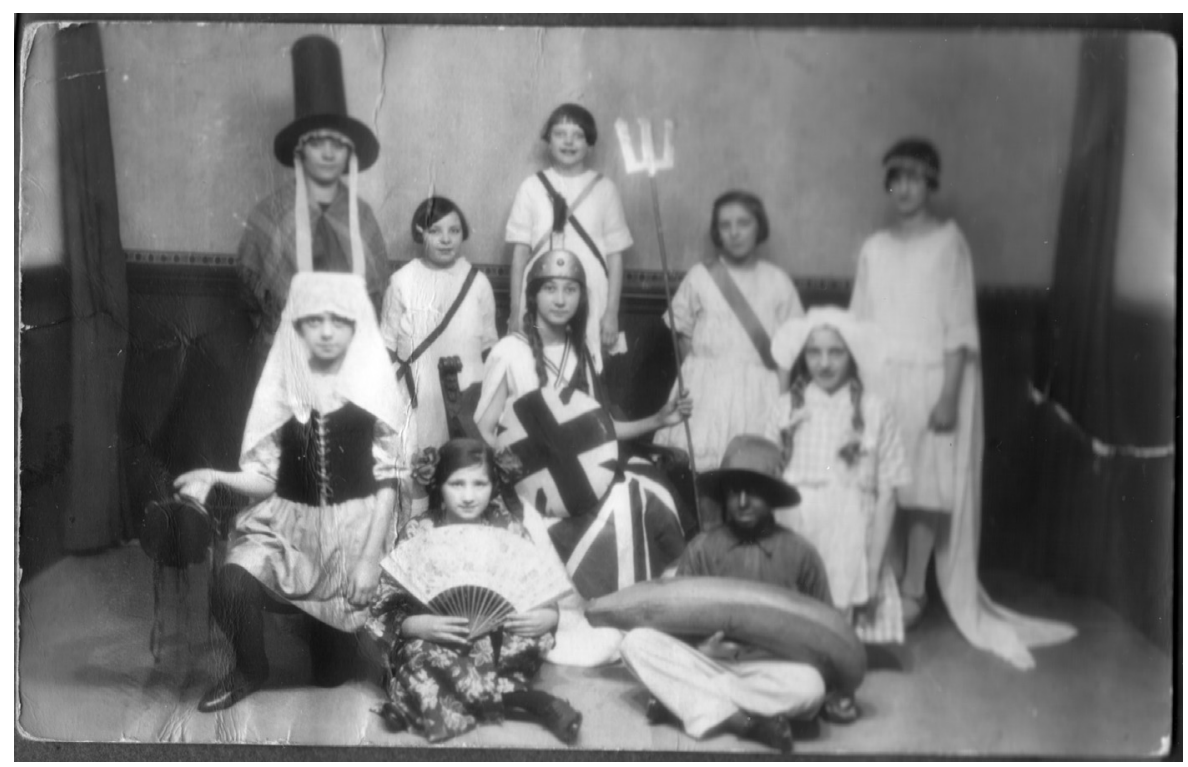

Figure 3. Britain's place in the world illustrated. Photo reproduced by permission of Mrs Janet Pickstock.

42 P. Veyne, 'Y a-t-il eu un impérialisme romain?', MEFRA 87 (1975), 793-855, at 796.

43 Bryce (n. 16), 9.

44 For nineteenth-century British writers on Persia, see, e.g., T. Harrison, "'Respectable in its ruins": Achaemenid Persia, ancient and modern', in L. Hardwick and C. Stray (eds.), Blackwell Companion to Classical Reception (Oxford, 2007).

45 See, e.g., E. W. Said, Culture and Imperialism (London, 1993), 10. 
of the last century, in which children are dressed as different peoples with my grandmother-in-law as Britannia.) And it is worth pointing out that the insight that empire was founded on broader educational/ideological foundations can be found much earlier than Edward Said. Arguably, it can be seen even in Polybius' account of the Roman constitution in Book 6 of his histories (which credits Roman success, for example, to aspects of Roman society, not least religious superstition). In the modern world, the same insight can be seen in the classicist Francis Cornford's ironic comparison of Roman law and College discipline in 1908: 'The Roman sword', he said, 'would never have conquered the world if the grand fabric of Roman Law had not been elaborated to save the man behind the sword from having to think for himself. ${ }^{46}$ In filling out the picture of ancient empire in this way, the trick is to expand the range of sources under examination - and crucially, in my view, to embrace literary texts that have too often been sidelined as part of somebody else's syllabus. In the first surviving Greek tragedy, The Persians, for example, I and others have argued for the expression of an Athenian democratic and imperial ideology in $472 \mathrm{BC}$, forty years before Thucydides began to write his History. ${ }^{47}$ Curiously, a number of literary critics had been interpreting the play as a critique of Athenian imperialism, while historians had denied - and persist in denying - the existence of any such ideology. ${ }^{48}$

So, if you follow me this far, the exercise of looking at earlier versions can help us in the reconstruction of the reality of ancient empires. I would go further, indeed, and claim that the study of classical reception (or to appease those who decry the increasing number of 'receptionists', the appreciation of the historical depth of our own interpretations of the classical past) is integral to a nuanced historical approach. But does it work in reverse? Can an understanding of ancient imperialisms cast light on contemporary experience? 'Don't study history', the veteran Israeli politician (and now President) Shimon Peres declared recently. 'There's nothing to study except a

${ }^{46}$ F. M. Cornford, Microcosmographia Academica. Being a Guide to the Young Academic Politician (Cambridge, 1908), reprinted as Cambridge's Classic Guide to Success in the World, 20, continuing: 'In the same way the British Empire is the outcome of College and School discipline and of the Church Catechism'.

${ }^{47}$ See, e.g., J. D. Craig, 'The Interpretation of Aeschylus' Persae', CR 38 (1924), 98-101; S. D. Goldhill, 'Battle Narrative and Politics in Aeschylus' Persae', fHS 108 (1988), 189-93; T. Harrison, The Emptiness of Asia. Aeschylus' Persians and the History of the Fifth Century (London, 2000).

48 See, e.g. recently, P. J. Rhodes, Athenian Democracy and Modern Ideology (London, 2003), 'Nothing to Do with Democracy: Athenian Drama and the Polis', $\mathcal{F H S} 123$ (2003), 104-19. 
chain of mistakes and many wars. Think rather than remember. What may happen has nothing to do with what has happened'. ${ }^{49}$ Seeing the examples of Cromer and others, it is tempting to suppose that the study of previous historians is likewise condemned to be a history of relentless failure. Needless to say - and not only because the ancient historian can hardly be seen acceding to the image of 'ancient history' as archetypally irrelevant - I will not be following this line.

As Frank Walbank wrote over fifty years ago,

Though the historian is apt to believe that the subject he has chosen for study is one which he came to by chance, or because it arose out of some earlier work, or for some other wholly personal reason, fifty years hence it will be quite obvious that the themes chosen by historians today, and the treatment accorded to them, were directly related to contemporary events. 50

This did not, for Walbank, undermine the value of the study of the ancient past:

if it is the needs of our own time which determine our selection of historical themes, are we not then entitled to receive from our studies in exchange...that wisdom which is the fruit of watching men partly like and partly unlike ourselves meeting, and either solving or failing to solve, problems that are partly like and partly unlike those which we ourselves have to face.

Walbank is drawing here on a tradition of thought that goes back in particular to Thucydides and Polybius (for example, Thuc. 1.22.4, Polyb. 12.25e.6). It is worth emphasizing, however, that for Polybius you needed to be engaged in the political world to appreciate the analogies between past and present; he was contemptuous of those 'who haunt the libraries... and then convince themselves that they are properly equipped for the task' (Polyb. 12.25f).

Modern writers, none of them (with the exception of Boris Johnson) directly politically active, have sought straightforward lessons from ancient empires for contemporary affairs - and continue to do so. 'Lesson 1 in the Roman handbook for imperial success', Jonathan Freedland wrote in 2002, 'would be a realisation that it is not enough to have great military strength: the rest of the world must know that strength - and fear it too'. ${ }^{51}$ The strategy of US 'shock and awe', of course, looks markedly less successful now than five years ago. With that hindsight, The Independent's Robert Fisk has suggested that

49 Quoted by A. Rusbridger, The Guardian, 27 January 2007, 30.

50 F. W. Walbank, 'The problem of Greek rationality', Phoenix 5 (1951), 41-60 at 59-60.

51 The Guardian, 18 September 2002. 
things might have turned out differently in Iraq if the Americans had followed the Romans' lead and given the Iraqis US citizenship - a point made in more general terms by Boris Johnson. ${ }^{52}$ And the Cambridge historian Christopher Kelly has warned the Americans, through The Guardian again, that 'What America will need to consider in the next 10 or 15 years is what is the optimum size for a nonterritorial empire, how interventionist will it be outside its borders, what degree of control will it wish to exercise, how directly, how much through local elites?" 53 You would suppose this laughable (fusty old, or sharp young, ancient historians cosying up to power) were it not for the influential position that ancient history has had on US policy. ${ }^{54}$

What other lessons can one draw? We can safely, I think, draw some negative lessons. A little more sensitivity to the historical patterns we have been looking at (in particular, the idea of the imperial balance sheet) might have saved the British Prime Minister from himself when, in one of his first forays into foreign affairs, he protested that we 'should celebrate...rather than apologise for [the British empire], and talk about enduring British values that grew in Britain and influenced the rest of the world'. ${ }^{55}$ (Brown's British values include such non-specific items as 'tolerance, liberty, civic duty...fair play, openness, internationalism'.) Brown, it seems, would find nothing to disagree with in Cromer's rejoinder to the Bengali protester. As one critic has replied, Brown was 'closing the door on Britain's period of national contrition before it had even begun'; his reference to Britain's internationalism, its 'uniquely rich, open and outward looking culture' are 'like saying that Bonnie and Clyde took a keen interest in the banking profession'. ${ }^{56}$

You can also, I think, draw some other more positive if indirect parallels between contemporary and ancient affairs. In the early years of the Iraq war, the pax Romana might have seemed a convincing analogy for US power: blandly benign in intentions, backed up with 'shock and awe'. Perhaps now the experience of the Athenian empire, held together by (an artificially sustained?) fear of the Persian enemy,

52 The Independent, 7 December 2006; cf. Johnson (n. 6), 107.

53 Quoted by Freedland (n. 50).

${ }^{54}$ I am thinking, for example, of the very different influences of Victor Davis Hanson (responsible for the thesis of a 'western way of war' rooted in democratic values, etc.) and the father-son team of Donald and Robert Kagan, Yale ancient historian and leading neocon respectively.

55 Interviewed for BBC's Newsnight, Monday 14 March 2005.

56 A. Patton, Don't Mention The Empire, available at <http://www.route57.group.shef.ac.uk/ non-fiction-08-empire.html>, accessed 14 November 2007. 
might seem to offer a better fit, just as it offers a model perhaps for the apparently paradoxical phenomenon of an empire exercised by a democracy or of an imperial ideology that represents itself as anti-imperial: as a 'city on a hill', in the words of the early American puritan John Winthrop; or an education to Greece, in the phrase of Thucydides' Pericles. We can enjoy the irony that Persian kings, derided for so long in the western tradition as archetypal tyrants, saw themselves as global policemen putting down others' petty squabbles. In the words of an inscription of Darius at Susa,

Provinces were in commotion; one man was smiting the other. The following I brought about by the favour of Ahuramazda, that the one does not smite the other at all, each one is in his place. My law, of that they feel fear, so that the stronger does not smite or destroy the weak. 57

This irony has been exploited by Tom Holland in his popular history of the Persian wars, Persian Fire, in representing Persia as a global superpower and Athens and Sparta as 'two terrorist states' hiding away in mountainous terrain like Osama bin Laden. ${ }^{58}$ In Persian imperial ideology, we can also see a model for the way in which empires tend to project their values as universal. (I have in mind the remark of an unnamed White House official to the journalist Ron Susskind: 'We're an empire now, and when we act, we create our own reality'. ${ }^{59}$ ) In the Persians' case, if you are within the empire, submitting to the king's power, you are in a world of order and 'truth', in which 'each one is in his place' and the king expresses his gratitude for benefactions with formalized gifts; if you are on the outside, living in a state of 'commotion' and subscribing to the 'lie', a different fate may await you.

In the light of the long history of such claims, we can also be cynical of any reference to civilizing missions or 'benevolent hegemony' and be quite clear that such claims elide with, if they are not actually a front for, self-interest. As with the Athenians who Thucydides portrays in negotiation with the island of Melos - who begin by declaring that they will not come out with any noble guff about their deserving their empire but instead will get down to brass tacks - there is not, anyway, much attempt to disguise this fact in the

57 R. G. Kent, Old Persian. Grammar, Texts, Lexicon (New Haven, CT, 1953) DSe 30-4; cf. $\mathrm{DNb} 16-21$.

58 T. Holland, Persian Fire (London, 2005). See, e.g., his cover blurb: 'It was 2500 years ago that East and West first went to war. Early in the early fifth century bc, a global superpower was determined to bring truth and order to what it regarded as two terrorist states'.

59 The Guardian, 10 February 2006, G2, 7. 
contemporary American context. In an article in which we can only suspect that the International Relations professor got the better of the political servant, Condoleeza Rice observed in 2000 that 'to be sure there is nothing wrong with doing something that benefits all humanity, but that is, in a sense, a second-order effect'. ${ }^{60}$ Perhaps most significantly, however, just as in the Athenian or Roman cases so also in the case of America we can find the claim of accidental imperialism, that the United States has only been drawn into quarrels of others' making. (As John Quincey Adams put it memorably in his oration of 4 July 1821, 'America goes not abroad in search of monsters to destroy'.) This claim has been exhaustively deconstructed in the American context by Robert Kagan in his recent book, Dangerous Nation, in language strikingly reminiscent of examples we have seen from the ancient world:

Americans have cherished an image of themselves as by nature inward-looking and aloof, only sporadically and spasmodically venturing forth into the world, usually in response to external attack or perceived threats. This self-image survives, despite four hundred years of steady expansion and an ever-deepening involvement in world affairs, and despite innumerable wars, interventions, and prolonged occupations in foreign lands. It is as if it were all an accident or an odd twist of fate. Even as the United States has risen to a position of global hegemony, expanding its reach and purview and involvement across the continent and then across the oceans, Americans still believe that their nation's natural tendencies are toward passivity, indifference, and insularity. ${ }^{61}$

The implication - like that of J. R. Seeley - is that Americans need to wake up to the real nature of their history and of their current global position. America's innocence may have made their power more palatable, he goes on (how could a nation so blithely unaware be really threatening?), but the downside for Kagan is that Americans have not begun to appreciate how their 'expansive tendencies...bump up against and intrude upon other peoples and cultures'.

Finally, ancient history provides parallels for how empires can draw on a number of contradictory examples in the creation of their identities. The Persian kings represented their rule as the summation of previous empires. So, in their art and architecture, for example in the tomb of Cyrus the Great at Pasargadae, they blended aspects from a number of the traditions of their subject peoples. (This was famously described, by Bernard Berenson, as the 'originality of incompetence',

${ }^{60}$ C. Rice, 'Promoting the national interest', Foreign Affairs 79.1 (January/February 2000), $45-62$ at 47.

${ }^{61}$ R. Kagan, Dangerous Nation. America and the World 1600-1898 (New York, NY, 2006), 5. 
but is now interpreted more generously. ${ }^{62}$ ) In a similar way, later empires have blithely appropriated both sides of ancient conflicts: the founders of the American republic looked to Athens, to Rome, and to Carthage; ${ }^{63}$ Britain and Germany moulded national heroes from the resistance to Roman power, Boadicea or Arminius/ Hermann - and then there is Asterix the Gaul. ${ }^{64}$ The implication of these multiple appropriations is that the new empire can blend the best features, whilst avoiding the faults, of its predecessors. Hence Alexander Hamilton's idea of the United States as the 'empire of liberty', or Buchan's notion of the Roman Empire getting a new lease of life from the infusion of the fresh blood of the conquered peoples. Buchan's Caesar (for a British man of action) spends a lot of time musing on the great future ahead for the provinces: 'If Rome was moribund' and this is in the mid-first century BC - 'her domains still had the stuff of life.... He had now a conception of a different type of empire - an empire of vigorous local life and culture.... ${ }^{65}$ When he first looks across the English channel from Gaul he has a more prophetic insight: 'he saw the distant cliffs of the "white land", and his explorer's interest was awakened by the strange island of the north from which the secret religion of the Gauls drew its inspiration'. ${ }^{66}$

Christianity adds another dimension to the translatio imperii, the succession of empires: Cromer, amongst many others, asserts the superiority of the British empire over the Roman on the grounds of its being founded on 'the granite rock of the Christian moral code'. ${ }^{67}$ The addition of Christianity seems to suggest that there is nowhere further to go, and yet implicit in this notion of the accumulation of imperial models, a kind of snowball effect, is that your empire too will be superseded. ${ }^{68}$ There is something of this pathos in Kipling's poem,

62 B. Berenson, Aesthetics and History (Garden City, NY, 1954), 186. For rebuttal, see especially C. Nylander, Ionians in Pasargadae (Uppsala, 1970); M. C. Root, The King and Kingship in Achaemenid Art. Essays in the Creation of an Iconography of Empire (Leiden, 1979); idem, 'From the Heart: Powerful Persianisms in the Art of the Western Empire', in H. Sancisi-Weerdenburg and A. Kuhrt (eds.), Achaemenid History VI. Asia Minor and Egypt. Old Cultures in a New Empire (Leiden, 1991), 1-29.

63 See C. Winterer, The Culture of Classicism. Ancient Greece and Rome in Ancient Intellectual Life 1780-1910 (Baltimore, MD, 2002).

${ }^{64}$ On whom, see K. Brodersen, Asterix und seine Zeit. Die große Welt des kleinen Galliers (Munich, 2001).

${ }^{65}$ Buchan (n. 17), 67; cf. 23, 82.

${ }^{66}$ Ibid., 47.

${ }^{67}$ E. Baring, Earl of Cromer, 'The Government of Subject Races', reprinted in his Political and Literary Essays 1908-1913 (London, 1914), 3-4; quoted by Owen (n. 18), 363.

68 A similar strain can be found in the confused triumphalism of Huntington's 'The Clash of Civilisations', Foreign Affairs 72.3 (Summer 1993), 22-49, cited from Huntington (n. 8), 3: 'Civilizations are dynamic; they rise and fall; they divide and merge. And, as any student of history knows, civilizations disappear and are buried in the sands of time.' 
the 'Roman Centurion's Song', in which the centurion begs his commander to let him stay to serve Britain: 'Let me work here for Britain's sake - at any task you will / A marsh to drain, a road to make or native troops to drill'; the civilizing mission is what is allowing Britain to begin to supersede Rome. ${ }^{69}$

This observation leads me to the final topic that I would like to discuss here: the insights that can be drawn from ancient accounts of empire - I am thinking here of the three great (Greek) historians of antiquity, Herodotus, Thucydides, and Polybius. It has often been said that the central theme of the great ancient historians is war. A good case can be made, at least with the tradition of 'great historiography' in Greek, that it is, in fact, empire (or at least, since the Greeks did not have an equivalent term, the domination by one power of others) that is the central theme. Greek historiography starts with a world before empire, indeed apparently before human contact. The opening of the Histories of Herodotus seem to envisage a world in which different populations are kept discrete. In what appears to be an initial contact, a Phoenician ship wends its way from the Red Sea through the Mediterranean to Argos, where the abduction of a girl, Io, sets off a series of reciprocal abductions that lead to the Trojan war. Contact, it seems to be suggested, inevitably leads to trouble and, as the Histories unfold, they present us with a progressive thickening of contact between peoples, as more and more protagonists are folded into the mix, until the process culminates in the war between the Greek-Persian wars. With Polybius, history comes to a close under the Roman empire. Before Roman power united the history of the known world, the oikoumene, history was a series of unrelated episodes. It is Roman power that makes history meaningful. ${ }^{70}$ In a famous veterinary analogy, he compares 'those who believe that they can obtain a just and well-proportioned view of history as a whole by reading separate and specialised reports of events' with the man who mistakes the examination of the dissected parts of an animal with the 'living creature in all its grace in movement' (Polyb. 1.4). The

${ }^{69}$ Also published under the titles 'The Roman Occupation of Britain - A.D. 300', 'The Roman Centurion Speaks', 'The Roman Centurion', and 'The Centurion's Song'; first published in Three Poems (Oxford, 1911), and shortly afterwards in C. R. L. Fletcher and R. Kipling, A School History of England (Oxford, 1911). See also Kipling's story, 'The Church that was at Antioch', first published in London Magazine (August 1929), 134-46; collected in Limits and Renewals (London, 1932).

70 See K. Clarke, Between Geography and History. Hellenistic Constructions of the Roman World (Oxford, 1999); J. Crawley Quinn, 'Imagining the Imperial Mediterranean', in B. J. Gibson and T. Harrison (eds.) Polybius (forthcoming). 
Roman conquest of the world is a finite story, 'a single action and a single spectacle, with an identifiable beginning, a fixed duration, and an acknowledged end' (3.1) - in 167 BC. (At that point, all he can do is to examine how the Romans exercised their unchallenged rule, and how others felt in response.) By virtue of possessing - a dubious claim - a unique balance of oligarchy, monarchy, and democracy, the Roman constitution in Polybius' view is preserved from degenerating. ${ }^{71}$

Of the three great Greek historians, it is Thucydides who gets all the attention for his representation of empire and international relations. His work, indeed, has been used in a bewildering variety of ways - it has even been called (by Irving Kristol) the 'favourite neoconservative text on foreign affairs (thanks in particular to Leo Strauss and to Donald Kagan)' ${ }^{72}$ My focus here will be on the one of the trio who has perhaps been underestimated as a 'theorist' of empire, the father of history, Herodotus. Herodotus asks a number of, perhaps surprisingly modern, questions about empire. ${ }^{73}$

Herodotus, for example, posits a link between power and geographical knowledge. It is striking, for example, how much of the geographical material in the Histories is introduced only in response to the Persian king's enquiry. It is Darius' wonder at the Black Sea, for example, which leads to Herodotus' reporting - tendentious - of how we measured it from end to end (Hdt. 4.85-6). Xerxes and other Persian Kings are always counting their troop numbers, measuring their land, surveying potential conquests, as if nervous of their power, and as if mapping were the same as mastering. ${ }^{74}$ Why do some peoples get the bug of empire and not others? Or why (in the language of Robert Kagan in his Paradise and Power) do some choose to run away from power in favour of (as Kagan says of Europe today) 'a post-historical paradise of peace and relative prosperity', 'to make a

71 Although the organic metaphors of growth and development of constitutions suggest the possibility of degeneration.

72 I. Kristol, 'The Neoconservative Persuasion. What it was and what it is', in Stelzer (n. 7), 35-6. For the fullest exploration of the relationship between International Relations and Classics, see now Polly Low, Interstate Relations in Classical Greece: Morality and Politics (Cambridge, 2007).

${ }^{73}$ For a further development of these thoughts, see my 'Herodotus on Empire', Classical World (forthcoming, 2008). I am grateful to Professors Paul Cartledge and Matthew Santirocco for the opportunity to give those ideas a trial at a conference, Herodotus Now, at New York University, March 2007.

${ }^{74}$ See further, T. Harrison, 'The Place of Geography in Herodotus' Histories' in C. Adams and J. Roy (eds.), Travel, Geography and Culture in Ancient Greece and the Near East (Oxford, 2007), 44-65. 
virtue out of weakness'? ${ }^{75}$ When the Persian king Cambyses sends messengers (in practice, spies) to the Ethiopians, the Ethiopian king sees through their real purpose easily and sends them packing with the warning that Cambyses 'should thank the gods for not turning the thoughts of the children of Ethiopia to foreign conquest' (Hdt. 3.21). What, though, will come next? Herodotus' Histories end with the expulsion of the Persian army from Europe and with hints that Athens is taking on the mantle of (an excessive) imperialism. ${ }^{76}$ There are ominous signs, however, that other peoples too could rise up. Will the Ethiopians remain Ethiopians, content with their own land? The Thracians, he notes at one point, could be the most powerful people and irresistible in war, were they either to find a single ruler or a single purpose (Hdt. 5.3). The future, it seems, is one in which other empires of which we have not even dreamed might loom large - and current empires disappear - or in which there will be just an increasing mêlée of powers, an increasingly 'multipolar' world. (Writing from London in 1817, John Quincey Adams observed similarly that 'the universal feeling in Europe in witnessing the gigantic growth of our [American] population and power is that we shall, if united, become a very dangerous member of the society of nations' ${ }^{77}$ )

Herodotus' focus on empire also asks questions about the role of the historian. If geographical knowledge, in his perspective, is inextricably associated with imperial expansion, how then could Herodotus fail to be self-conscious in writing a work that, by implication, is not only a reflection of aggressive expansion but will also facilitate it? To borrow the formula of Simon Gikandi, is Herodotus a critic or a proponent of an 'imperialized knowledge'? ${ }^{78}$ This question takes us to the heart of the Histories, to the larger conundrum of the extent to which Herodotus' agents can act to avert their fates. (This is a strand in ancient historiography in my view that runs in parallel to the emphasis on history's utility, and that has been underestimated. Even for the pragmatic Polybius, history is partly useful in so far as it teaches one how 'to bear with dignity the vicissitudes of fortune', 1.1.) A good example of this is the scene in which Xerxes, having

\footnotetext{
75 Robert Kagan, Paradise and Power. American and Europe in the New World Order (revised edition, London, 2004; originally published 2003), 3, 13.

76 See, e.g., C. W. Fornara, Herodotus. An Interpretative Essay (Oxford, 1971); P. Stadter, 'Herodotus and the Athenian Arche', ASNP 22 (1992), 781-809; J. Moles, 'Herodotus Warns the Athenians', Papers of the Leeds International Latin Seminar 9 (1996), 259-84.

77 Quoted by Kagan (n. 75), 137.

78 S. Gikandi, Maps of Englishness. Writing Identity in the Culture of Colonialism (New York, NY, 1996), esp. ch. 3.
} 
committed himself to a vast expedition against Greece and having surveyed all his fleet laid out before him at the Hellespont, bursts into tears (7.45-52). 'I was thinking', he tells his uncle, 'and it came into my mind how pitifully short human life is - for of all of these thousands of men, not one will be alive in a hundred years.' Artabanus, his uncle, tries to cheer him up by telling him that there are worse things than that, and then they aimlessly discuss whether the decision to invade Greece was, in fact, the right one. Would they have stuck to their plan if they had not been told, very forcefully, to do so in a series of dreams? I thought of this episode recently - not quite in a dream, but on a train - when reading the final passage of Bob Woodward's account of the build-up to the Iraq war, Plan of Attack - and it is with this wistful anecdote that I will end. ${ }^{79}$ Woodward asks Bush how history would judge the war. There will probably be cycles, he suggests to the President; and he tells him of how Karl Rove believes that all history is measured by outcomes. 'Bush smiled. "History", he said, shrugging, taking his hands out of his pockets, extending his arms out and suggesting with his body language that it was so far off. "We won't know. We'll all be dead".'

79 B. Woodward, Plan of Attack (London, 2004), 443. 